\title{
Article
}

\section{Reforestation of Degraded Landscapes in Micronesia}

\author{
James B. Friday ${ }^{1, *}$, Diane L. Haase ${ }^{2}$, Ruddy Estoy ${ }^{3}$, James Manglona ${ }^{4}$ and Ryan Talken ${ }^{5}$ \\ 1 Cooperative Extension Service, University of Hawai'i, Hilo, HI 96720, USA \\ 2 U.S. Department of Agriculture, Forest Service, Reforestation, Nurseries, and Genetic Resources, \\ Portland, OR 97204, USA; diane.haase@usda.gov \\ 3 Guam Division of Forestry and Soil Resources, Mangilao, GU 96913, USA; ruddy.estoy@doag.guam.gov \\ 4 Rota Department of Lands and Natural Resources, Rota, MP 96951, USA; rotaforestry@gmail.com \\ 5 Yap Department of Agriculture and Forestry, Yap, FM 96943, Federated States of Micronesia; \\ rtalken@gmail.com \\ * Correspondence: jbfriday@hawaii.edu
}

Citation: Friday, J.B.; Haase, D.L.;

Estoy, R.; Manglona, J.; Talken, R.

Reforestation of Degraded

Landscapes in Micronesia. Land 2021,

10, 926. https://doi.org/10.3390/

land10090926

Academic Editor: Eddie J. B.

van Etten

Received: 31 July 2021

Accepted: 29 August 2021

Published: 3 September 2021

Publisher's Note: MDPI stays neutral with regard to jurisdictional claims in published maps and institutional affiliations.

\section{Copyright: (c) 2021 by the authors.} Licensee MDPI, Basel, Switzerland. This article is an open access article distributed under the terms and conditions of the Creative Commons Attribution (CC BY) license (https:// creativecommons.org/licenses/by/ $4.0 /)$.

\begin{abstract}
Wildfires on degraded grasslands cause extensive soil erosion and cause environmental and economic damage worldwide. We conducted fertilizer, lime, and mulch trials to improve growth of trees planted in acid soils in degraded grasslands on the Micronesian islands of Guam, Rota, and Yap. Fertilizer application had no effect on height growth of Acacia auriculiformis seedlings on a Mollisol on Guam while lime application had a small but significant positive effect on height growth. Fertilizer application had a significant positive effect on height growth of Acacia confusa seedlings planted on an Oxisol on Rota but lime had no effect. Mulch application increased height growth of Swietenia macrophylla seedlings planted on an Oxisol on Yap but lime application had no effect. Collaboration between university researchers and local forestry agencies can improve reforestation success, but researchers need to consider local capabilities and local knowledge.
\end{abstract}

Keywords: afforestation; restoration; acid soils; wildfire; adaptive management; Acacia; Swietenia

\section{Introduction}

Reforestation and afforestation of fire-prone grasslands are priorities worldwide [1,2]. While fire can be a naturally occurring ecosystem process where local flora and fauna are adapted to wildfires, e.g., [3], anthropogenic fires are one of the major causes of tropical forest destruction worldwide [4,5]. Forestry agencies commonly attempt to reduce size and frequency of wildfires by planting trees to shade out fire-prone vegetation. Commercial plantations and public agencies are often able to draw on the expertise of company scientists in guiding afforestation efforts, but local or provincial agencies in many countries have limited expertise and few resources to draw upon. We conducted a series of trials on the Micronesian islands of Guam, Rota (Commonwealth of the Northern Mariana Islands), and Yap (Federated States of Micronesia) in coordination with local forestry agencies. The immediate goal of the trials was to test solutions for improving success in reforestation, while the larger goal was to explore ways small agencies in isolated areas can develop adaptive management processes to improve their reforestation success.

The islands of western Micronesia (Figure 1) have supported human populations for thousands of years, and the earliest inhabitants used fire to clear land for agriculture [6-9]. While the islands still retain significant areas of native forests, there are also wide areas where forests were previously cleared and have regenerated with fire-prone stands of grasses and ferns [7,10-12]. 


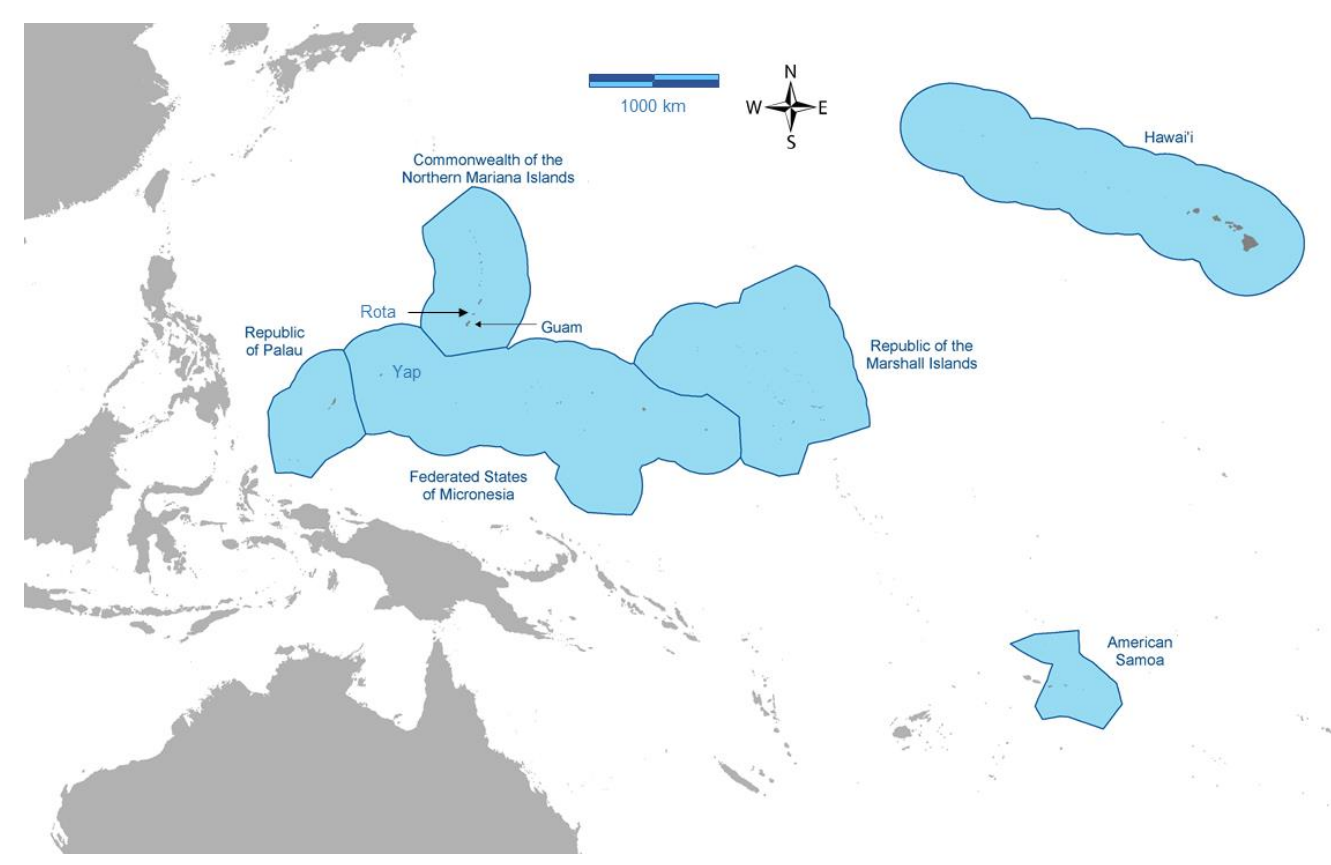

Figure 1. Map of the American-affiliated Pacific Islands of Micronesia, including Guam, Yap, and Rota. Reproduced by permission from Pacific RISA, US National Oceanic and Atmospheric Administration, pacificrisa.org.

Frequent wildfires prevent forests from naturally regenerating in these areas. Almost all wildfires in Micronesia are human caused, either accidentally, or intentionally started by hunters to clear dense vegetation and increase grass growth to attract game $[9,13]$. On some islands (e.g., Palau) the amount of land cover with fire-prone grass and ferns seems to be relatively stable, as forests are able to recolonize burnt areas [14]. Other islands, however, are experiencing increases in wildfires (e.g., Hawai'i) and concomitant decreases in forest lands [15]. Overall, the islands of the Western Pacific are extremely vulnerable to wildfires, and large percentages of the islands burn annually [16]. In 2019 wildfires affected 7.1\% of the overall area of Guam, $8.2 \%$ of Rota, and $0.7 \%$ of Yap [13].

In the islands' seasonal climate, with a pronounced dry season followed by monsoon rains [17], wildfires remove ground cover, thereby increasing soil erosion during the rainy season [9,18-20] (Figure 2). Because of the small size of the islands, soil lost from upland areas is quickly deposited in near-shore areas where it impacts both coral reefs and local fisheries [9,18,21]. High levels of sediment in the water can block light the coral need for growth, and direct sediment deposition onto corals can negatively impact coral health [22]. Over time, "badlands" have developed on the most impacted sites where all the soil has been eroded away and only the weathered volcanic rock remains [23]. Soil erosion leads to increased runoff and decreased recharge of island aquifers, a concern expressed by resource managers on Yap and Palau [24]. Wildfires also endanger farms, rural dwellings, and local communities.

Forestry agencies on each island have conducted afforestation programs for decades and have had success on better sites $[18,19,25]$. On poorer sites, especially those with acid soils, growth and survival of planted forest seedlings has been mixed [19] (Figure 3).

Because many plantings have been lost to wildfires, one of the program goals is to hasten crown closure in new plantations which will shade out the grass that provides fuel for wildfires. We worked with existing programs to assess site quality and limitations to then develop site-specific recommendations for soil amendments with potential to improve seedling survival and growth. 


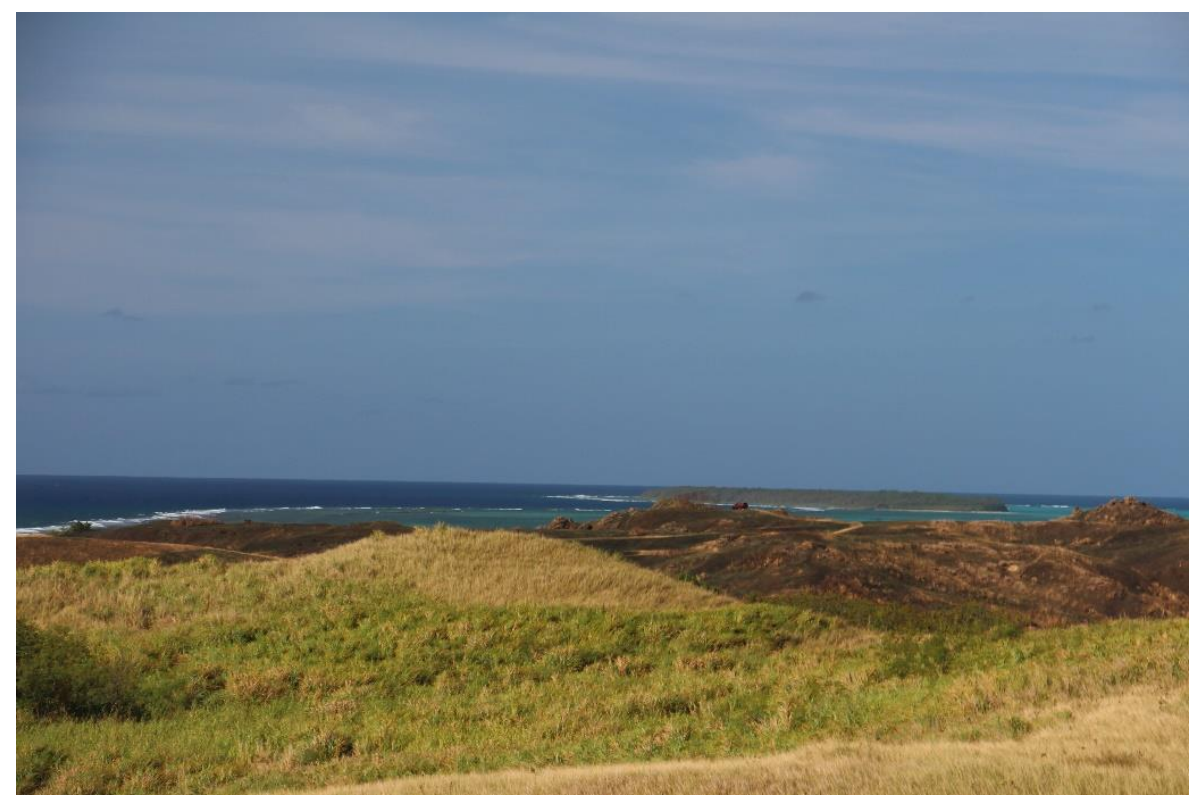

Figure 2. Grasslands of southern Guam showing coral reefs downslope from burned areas.

All three islands have a mixture of acid soils and more neutral soils spread across the landscape, indicating that a one-size-fits-all protocol for tree planting is not optimal [23]. Soils on the northern half of Guam are shallow soils over limestone deposits and are slightly acid to neutral Mollisols and Entisols, whereas soils on the southern half of the island are derived from a variety of volcanic deposits and include strongly acid Oxisols $[10,26]$. Rota geology is similar to northern Guam with mostly neutral soils on limestone landscapes and acid soils developed on small areas of exposed volcanic rock [19]. Yap has three main groups of soils: acid Oxisols derived from highly weathered volcanic rock, Alfisols and Mollisols developed from schist, and alluvial soils [27,28]. Yapese people recognize these different soil types and call volcanic oxisols "toomorag" and soils developed from metamorphic rocks "maadal" in their language.

The afforestation program on Guam has been largely agency-driven, with plantings of the non-native, nitrogen-fixing Acacia auriculiformis A. Cunn. ex Benth. used to shade out highly flammable grasses, then native tree species planted underneath [29]. As Guam lacks a forest industry, harvesting of the Acacia trees is not envisioned other than some possible minor uses for posts and firewood; instead, the plantations are intended as an intermediate stage in restoring native vegetation to the sites. This planting strategy has been successful in reforesting areas on relatively level ground, but on steeper slopes where wildfires are more difficult to control, frequent fires have destroyed many plantings before crown closure. On the island of Rota, foresters plant the non-native, nitrogen-fixing Acacia confusa Merr. to shade out grasses, and also plant vetiver grass (Chrysopogon zizanioides [L.] Nash) to slow erosion and plug developing gullies in badlands $[11,19]$. Although $A$. confusa grows more slowly than A. auriculiformis, local foresters prefer the species because of a long history of planting it on the island beginning with the pre-WWII Japanese administration [19]. Large populations of introduced deer (Rusa marianna) limit regeneration of native plant species on both Guam and Rota, while the non-native Acacia spp. are only lightly browsed by the deer. Although deer are not native to the islands, they have been there for generations and are valued by local communities as a food source. Projects on both Guam and Rota are intended to protect nearby coral reefs from siltation caused by up-slope erosion $[18,19,30]$. On Yap, wildfires have directly threatened local communities [27]. Community members are working with Yap Forestry to plant tree belts to protect communities and agroforests from wildfires originating in adjacent fern-dominated barrens on acid soils. The trees chosen include the non-native Swietenia macrophylla King, which is well-established in other plantings on the island and used for timber, the native Calophyllum inophyllum L., which 
also yields valuable timber, and other native species used locally for both food and timber. While the Yap program is more community-focused [27], each island is small enough that many workers on the reforestation projects also live in adjacent communities and have a stake in their success.

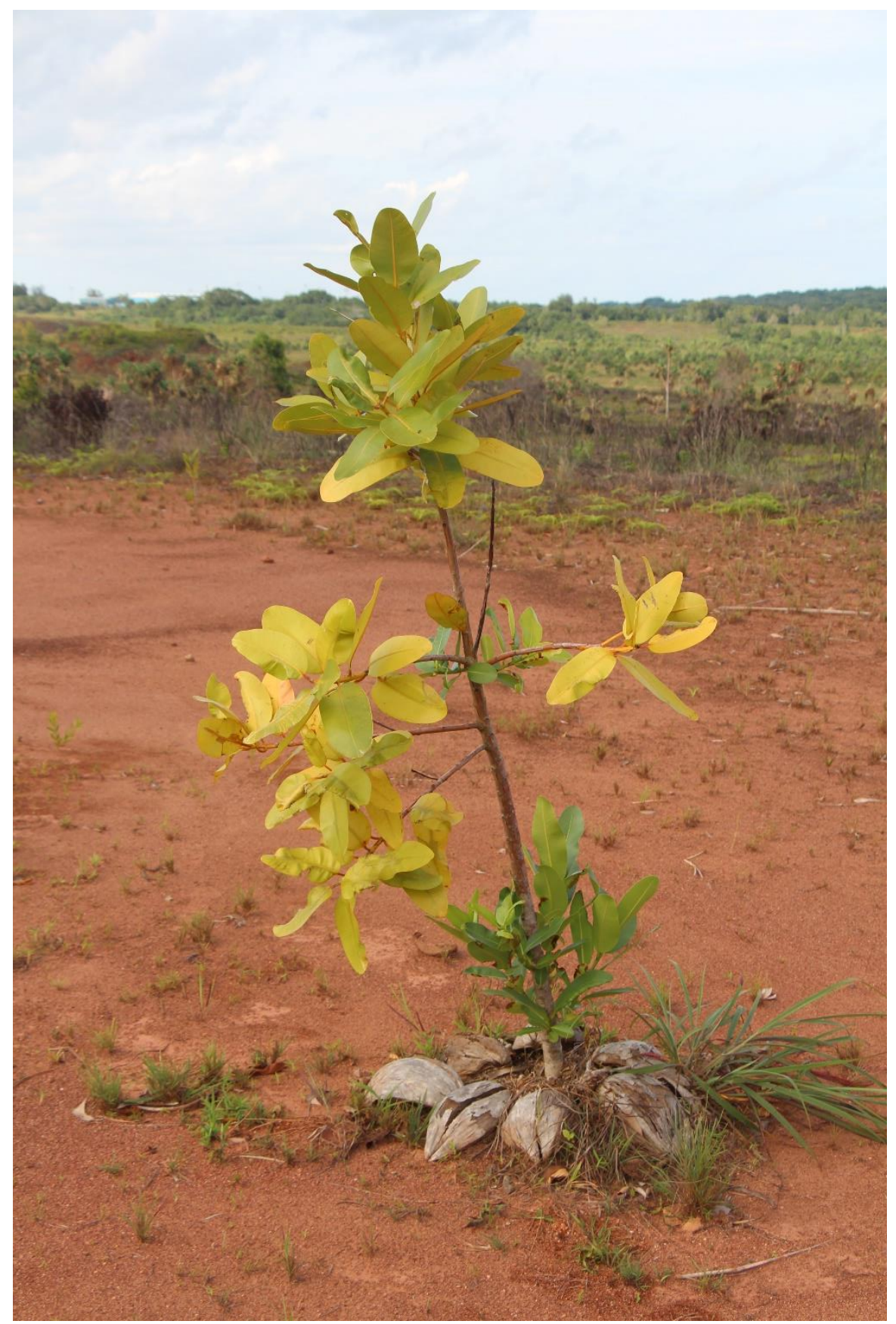

Figure 3. Chlorotic Calophyllum inophyllum seedling in an Oxisol on Yap, Federated States of Micronesia.

Treatments for each project included the island's standard practices compared with other treatments that were chosen based on local ideas and locally available materials. While all three islands have commercial agricultural supply stores, only Guam has regular shipments of supplies. Our goal was to guide local agencies in gradually improving reforestation practices through simple experimentation and adaptive management, following the Target Plant Concept [31], where plants are selected based on known limiting factors 
at the site, outplanted and subsequently evaluated, and the knowledge gained is used to improve seedlings for the next cycle.

\section{Materials and Methods}

Field sites on each island were chosen by the local forestry agencies based on local priorities.

\subsection{Guam}

The Guam site was established in the Cotal forest reserve, $\left(13^{\circ} 23^{\prime \prime} 25.14^{\prime \prime} \mathrm{N}\right.$ and $144^{\circ} 43^{\prime} 5.95^{\prime \prime}$ E, $140 \mathrm{~m}$ asl). Existing vegetation was dominated by swordgrass (Miscanthus floridulus [Labill.] Warb. Ex K. Schum. \& Lauterb.) which regenerated after a fire. Previous plantations of Acacia auriculiformis at this site had performed poorly and were stunted and chlorotic years after planting. Soils were mapped as the Agfayan-rock outcrop complex, where the Agfayan series is a clayey, smectitic, isohyperthermic, Udic Haplustoll [23], shallow but relatively fertile with about $30 \mathrm{~cm}$ topsoil over soft volcanic bedrock. The series is also associated with the Akina series, which is a very fine, kaolinitic, isohyperthermic Inceptic Haplustox. Rainfall is highly seasonal, with an annual average of $2500 \mathrm{~mm}$, mostly concentrated in a wet season of July through November.

A soil sample consisting of ten subsamples was collected from the site in January 2018. The upper horizon from soil depths of $0-10 \mathrm{~cm}$ and the lower horizon from depths $10-30 \mathrm{~cm}$ were collected separately [32]. Soil pH was tested using a handheld $\mathrm{pH}$ meter (Bluelab soil $\mathrm{pH}$ pen, New Zealand, bluelab.com) immediately after collection. Soil samples were then analyzed at the University of Guam soils laboratory rather than at a larger laboratory at the University of Hawai'i because local agencies would be more likely to make future use of the local facility in Guam than to ship samples to Hawai'i.

Vegetation at the site was controlled mechanically followed by an application of glyphosate approximately one month before planting. The experiment was laid out in a replicated complete block design with four blocks and eight seedlings per plot per treatment. Blocks were used to account for variations along the steep slope on the site. Acacia auriculiformis seedlings were grown in $262 \mathrm{~cm}^{3}$ individual Deepot ${ }^{\mathrm{TM}}$ cells (Stuewe and Sons, Tangent, OR, USA) for six months to heights of approximately $60 \mathrm{~cm}$ and planted in August 2018. Seedlings were inoculated with Rhizobium in the nursery. Treatments were a complete factorial consisting of three levels of fertilizer applied at the time of planting and with or without lime. Since standard practice was to apply $15 \mathrm{~g}$ of Osmocote ${ }^{\circledR} 14-14-14$ (NPK) fertilizer at planting, the three fertilizer treatments were $1 x, 2 x$, and $5 x$ standard practice (15 $\mathrm{g}, 30 \mathrm{~g}$, and $75 \mathrm{~g}$, respectively) per tree (Table 1).

Table 1. Fertilizer treatments applied in the Guam trial.

\begin{tabular}{cccc}
\hline & $\mathbf{N}$ & $\mathbf{P}_{\mathbf{2}} \mathbf{O}_{\mathbf{5}}$ & $\mathbf{K}_{\mathbf{2}} \mathbf{O}$ \\
\hline nominal \% & 14 & 14 & 14 \\
$($ elemental NPK \%) & $(14)$ & $(6.1)$ & $(11.6)$ \\
\hline Treatment & & Element per seedling $(\mathrm{g})$ & \\
\hline $1 \mathrm{x}$ & 3.9 & 1.7 & 3.3 \\
$2 \mathrm{x}$ & 7.8 & 3.4 & 6.5 \\
$5 \mathrm{x}$ & 19.6 & 8.6 & 16.3 \\
\hline
\end{tabular}

The labeled release rate for the fertilizer was 2 to 3 months at temperatures of $26^{\circ} \mathrm{C}$, which is typical of Guam. Fertilizer was applied in a hole immediately adjacent to the seedling. Lime was $400 \mathrm{~g}$ of pelletized dolomite and was applied into four holes dug within $40 \mathrm{~cm}$ of each seedling. Seedling heights were measured immediately after planting and again in July 2019, 11 months after planting. 


\subsection{Rota}

The Rota site was on a badly eroded slope on the Talakhaya badlands in a location called Asonan (14 ${ }^{\circ} 7^{\prime} 26.364^{\prime \prime} \mathrm{N}, 145^{\circ} 12^{\prime} 6.12^{\prime \prime}$ E, $195 \mathrm{~m}$ asl) (Figure 4).

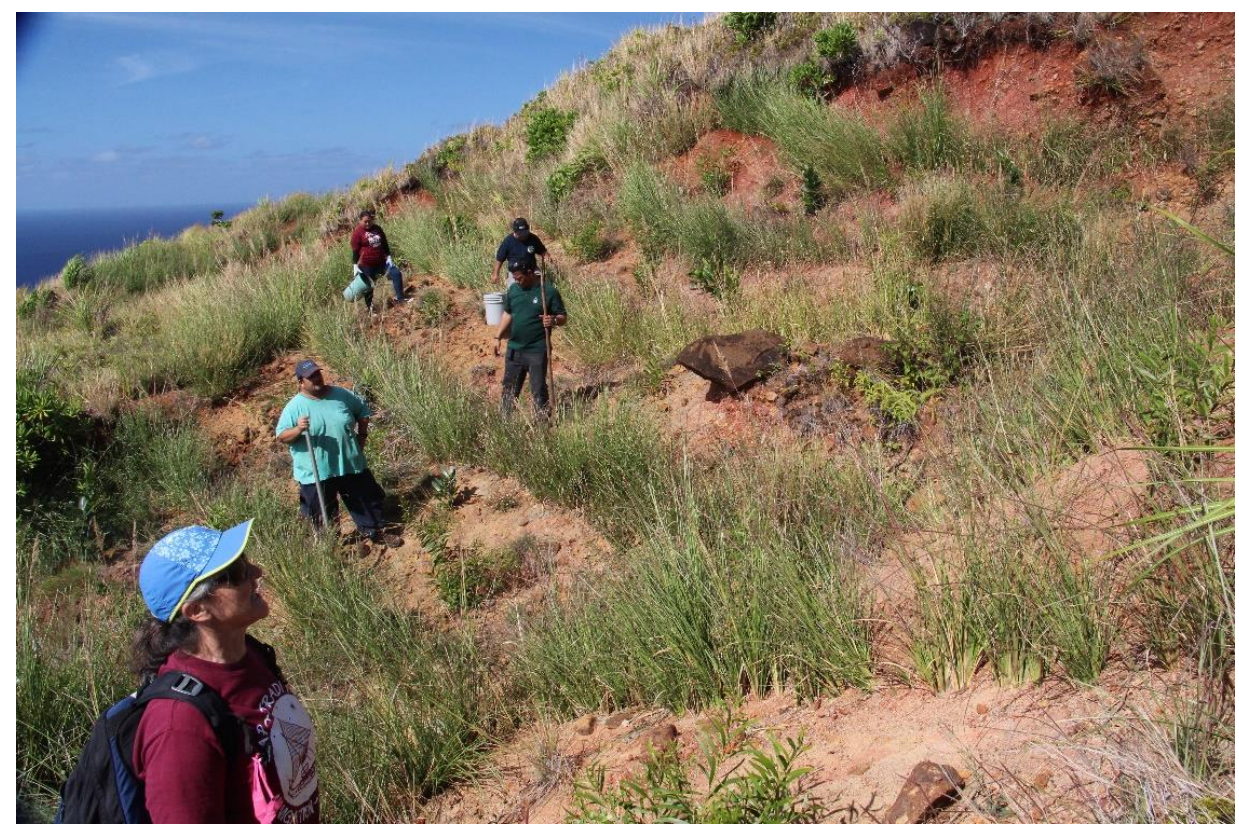

Figure 4. Planting Acacia confusa and vetiver grass on an eroded Oxisol on the island of Rota, Commonwealth of the Northern Marianas Islands.

The soils series was mapped as the Akina-badland complex [23]. The badlands are sites where the overlaying soil has eroded away, leaving dense, highly weathered volcanic rock. Similar to Guam, rainfall is highly seasonal, with an annual average of $2400 \mathrm{~mm}$, mostly concentrated in the wet season from July through November.

Soils were sampled January 2018 in the same manner as at the Guam site with composite samples sent for analysis. Soil $\mathrm{pH}$ values were tested immediately after sampling with a handheld $\mathrm{pH}$ meter (Bluelab soil $\mathrm{pH}$ pen, New Zealand, bluelab.com) in addition to being analyzed in the lab.

The experimental design was a randomized complete block with fertilizer and lime treatments. The four blocks were arranged to compensate for the site's steep slope. Eight trees were planted per plot per treatment. The standard fertilizer practice is to apply two tablets (Best Tabs 20-10-5 controlled-release fertilizer tablets, JR Simplot Co., Lathrop, CA, USA) per tree. Fertilizer treatments were to apply two $(1 \times)$ or four $(2 \times)$ tablets per tree (Table 2). The liming material was coarse, crushed coral, locally called manufactured sand, which is abundant on the island.

Table 2. Fertilizer treatments applied in the Rota trial.

\begin{tabular}{cccc}
\hline & $\mathbf{N}$ & $\mathbf{P}_{\mathbf{2}} \mathbf{O}_{\mathbf{5}}$ & $\mathbf{K}_{\mathbf{2}} \mathbf{O}$ \\
\hline $\begin{array}{c}\text { nominal \% } \\
(\text { elemental NPK \%) }\end{array}$ & 20 & 10 & 5 \\
\hline Treatment & $(20)$ & $(4.4)$ & $(4.2)$ \\
\hline $1 \mathrm{X}$ & 8.4 & Element per seedling $(\mathrm{g})$ \\
$2 \mathrm{x}$ & 16.8 & 1.8 & 1.7 \\
\hline
\end{tabular}

Acacia confusa seedlings were planted in August 2018. Seedlings averaged $50 \mathrm{~cm}$ tall and were grown in $656 \mathrm{~cm}^{3}$ individual Deepot ${ }^{\mathrm{TM}}$ cells (Stuewe and Sons, Tangent, OR, USA). Seedlings had developed nodules in the nursery, but many of the nodules appeared 
whitish or brown in color at the time of planting, indicating that the Rhizobium was missing or dead such that nodulation may not have resulted in effective nitrogen fixation. Existing vegetation on the site was sparse, so no vegetation control was needed prior to planting. Planting holes were dug by hand with lime mixed into the soil. Half the tablets were placed at the bottom of the hole and half were placed in the soil as the hole was filled. Microsite conditions varied with some seedlings planted into soil and others planted directly into the saprolite that was left after the site had been severely eroded. Seedling heights were measured at planting and again after 7 months and 25 months.

\subsection{Yap}

The Yap site was adjacent to the village of Tomil $\left(9^{\circ} 31^{\prime} 58.476^{\prime \prime} \mathrm{N}, 138^{\circ} 9^{\prime} 13.68^{\prime \prime} \mathrm{E}\right.$, $15 \mathrm{~m}$ asl). Soils were mapped as Gagil series, a fine, sesquic, isohyperthermic Typic Haploperox [23]. Average annual rainfall on the island is $3100 \mathrm{~mm}$ with a short dry season from February through April. Soils were sampled January 2018 in a similar manner as at the Guam site. Immediately after sampling, $\mathrm{pH}$ values were tested with a handheld $\mathrm{pH}$ meter (model HI 9813-5, Hanna Instruments, www.hannainst.com).

Treatments were applied to a three-year-old plantation of Swietenia macrophylla. Trees had been fertilized at planting with about $75 \mathrm{~g}$ of Osmocote ${ }^{\circledR} 14-14-14$ (NPK) slow-release fertilizer and a mulch of coconut husks had been applied around the base of each tree to a radius of about $20 \mathrm{~cm}$. Fertilizer was subsequently applied one to four times per year with approximate $75 \mathrm{~g}$ into holes around each seedling as needed. Fertilizer had been applied once in 2018 prior to the trial. Roots were observed to be restricted to the soil under the mulch ring without extending further out into the soil.

Vegetation was sparse to non-existent at the site, so no vegetation control was performed. Two separate experiments were installed on Yap in August 2018. Each trial consisted of four blocks and two treatments with eight trees per plot per treatment. In the first experiment, lime (quicklime, $\mathrm{CaO}$ ) was applied at a rate of $2.7 \mathrm{~kg} /$ tree and incorporated into the soil with a hand tractor in a $1.1 \mathrm{~m}$ radius around the stem (Figure 5) with control trees left unlimed. The amount of lime was calculated to be enough to raise soil $\mathrm{pH}$ by one unit. Yap Forestry had stocks of $\mathrm{CaO}$ available; commercial lime and fertilizers are only available in small quantities on the island.

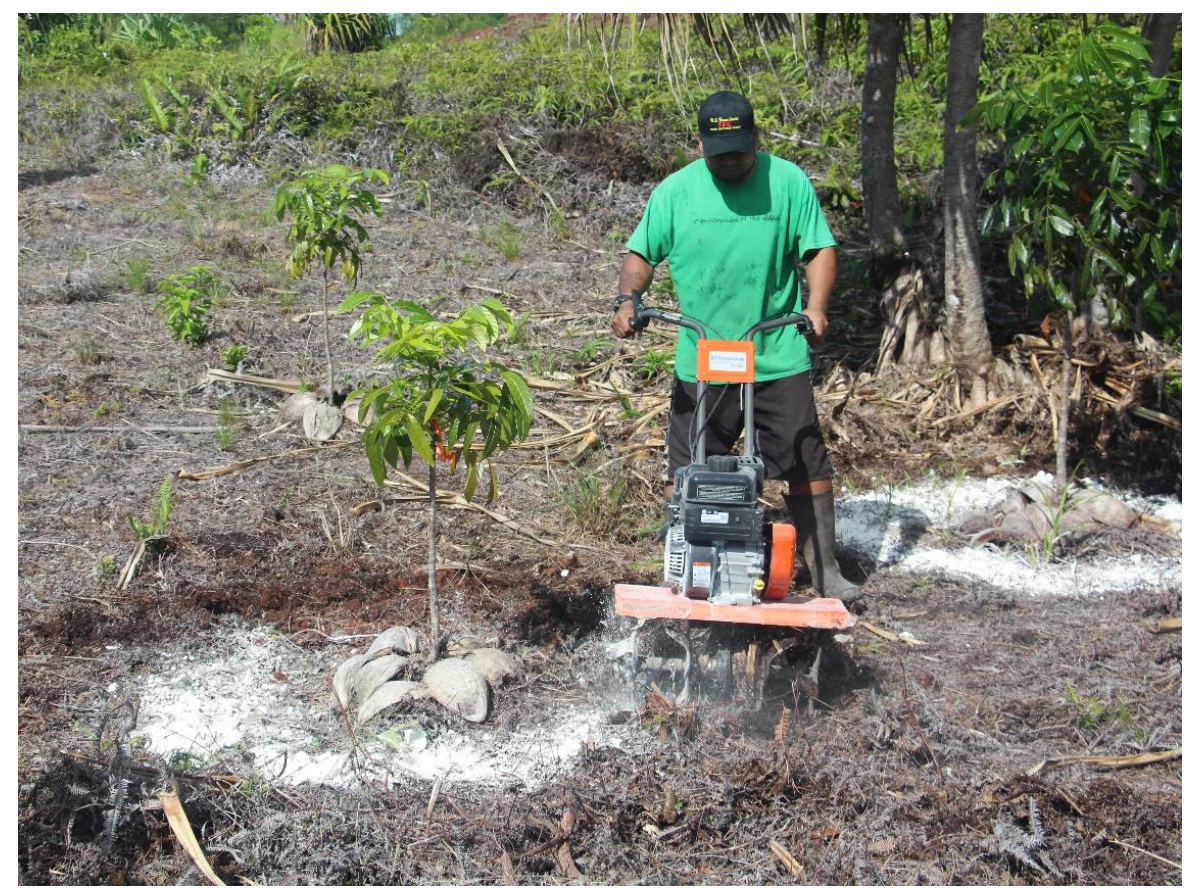

Figure 5. Applying lime $(\mathrm{CaO})$ with a hand tiller to Swietenia macrophylla seedlings on Yap, Federated States of Micronesia. 
For the second trial, both the Yap foresters and the local community wanted to test the traditional method of mulching with fresh organic matter. A layer of mulch made with freshly chipped branches and leaves of the local native shrub Hibiscus tiliaceus L. approximately $10 \mathrm{~cm}$ thick was applied in a ring around experimental trees to a radius of $80 \mathrm{~cm}$ (Figure 6).

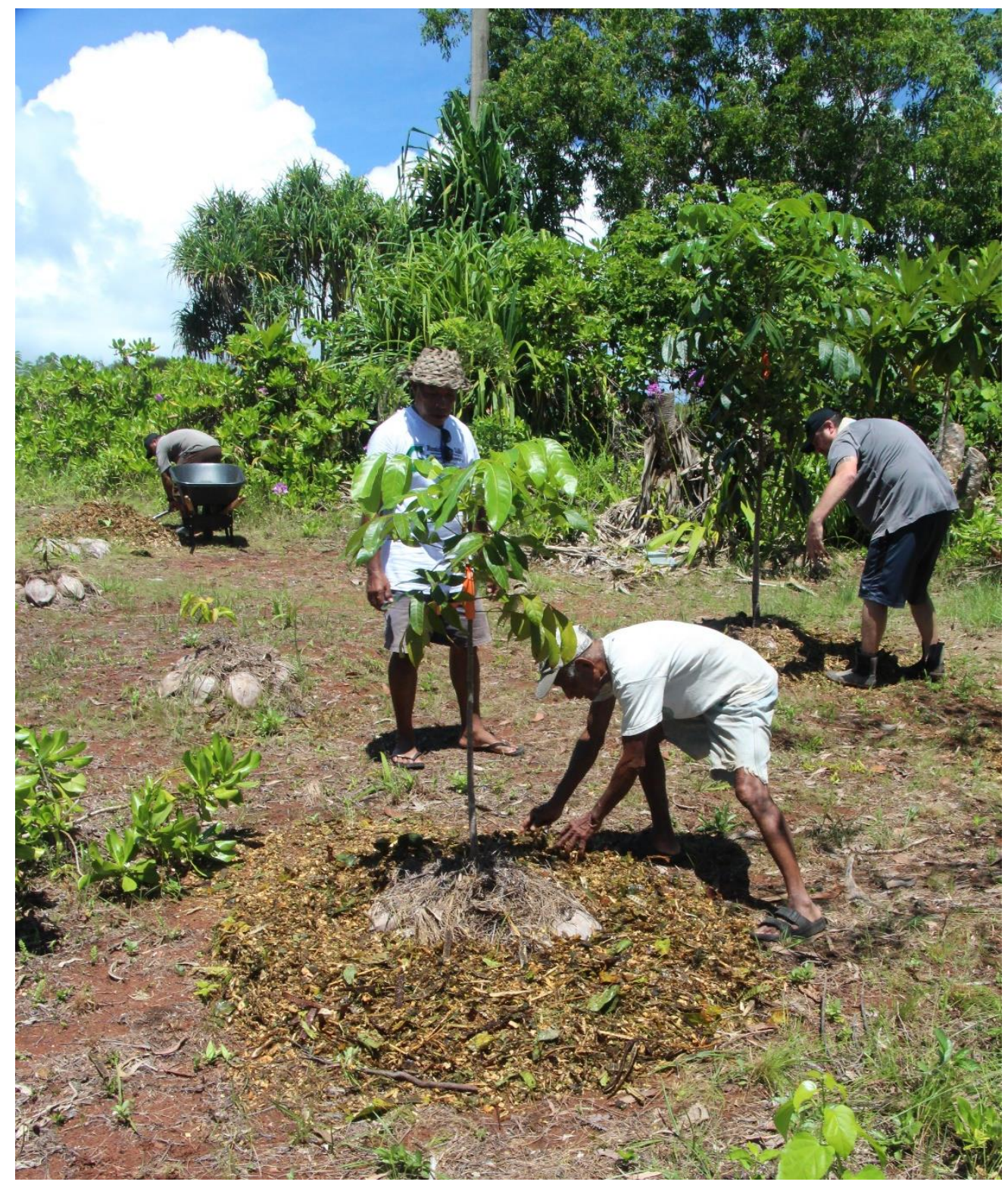

Figure 6. Fresh wood chip mulch applied to Swietenia macrophylla seedlings on Yap, Federated States of Micronesia.

Seedling heights were measured at planting and again after 11 months.

\subsection{Soil Analysis}

Soil analysis for all three sites was performed at the University of Guam soil lab. Samples were analyzed for $\mathrm{pH}$, total $\mathrm{N}$, available $\mathrm{P}, \mathrm{K}, \mathrm{Ca}, \mathrm{Mg}$, and total C. Cations were extracted with $1 \mathrm{~N}$ ammonium acetate and measured on a Perkin-Elmer Atomic Absorption Spectrophotometer (Model 305B, Waltham, MA, USA). Carbon and nitrogen levels were measured on a C-N analyzer (Flash Smart Elemental Analyzer, CE Elantech Company, Lakewood, NJ, USA). Because the University of Guam used the Oleson method 
for P extraction [33], which is more suited to alkaline soils, samples were also sent to the University of Florida and analyzed for P using the Mehlich III method.

\subsection{Data Analysis}

Statistical analysis for data from each site was performed using Statistix 10 (Tallahassee, FL, USA) to determine treatment differences for seedling height increment (calculated as the difference between height at the beginning of the experiment and the end of the experiment) and relative height growth (calculated as the height increment divided by the initial height). Guam and Rota data were analyzed using ANOVA for a complete factorial design. On the Guam site, deer browse was observed on $13 \%$ of the seedlings and these were omitted from the calculations. Rota data from one-year growth and for the entire two-year period were analyzed separately. Yap data were analyzed using a one-way ANOVA for each trial.

\section{Results}

\subsection{Soils}

Soils at the Guam site were very strongly acid in the top $10 \mathrm{~cm}$ with low total $\mathrm{N}$ and very low levels of available $\mathrm{P}$ (Table 3). These characteristics were more consistent with the Akina series than the Agfayan series that was mapped at the location. $\mathrm{K}$ and Ca levels were high, and $\mathrm{Mg}$ levels very high. Total organic matter, if calculated at 1.7 times percent C [34], was $6.7 \%$ in the upper $10 \mathrm{~cm}$ of the soil profile. Soils at the Rota site were similar to the Guam soils, with strongly acid reactions, very low total $\mathrm{N}$ and available $\mathrm{P}$, and high cation levels (Table 3). Organic matter was 5.3\% in the upper $10 \mathrm{~cm}$. Soils at the Yap site were more weathered with strongly acid $\mathrm{pH}$, low levels of total $\mathrm{N}$, and very low levels of extractable P, but with low cation levels as well (Table 3). Organic matter was lower, with only $3.8 \%$ in the upper $10 \mathrm{~cm}$.

Table 3. Soil characteristics at each site.

\begin{tabular}{ccccccccc}
\hline Site & Depth $\mathbf{( c m )}$ & $\mathbf{p H}$ & $\begin{array}{c}\text { Total N } \\
\mathbf{( \% )}\end{array}$ & $\begin{array}{c}\mathbf{P} \\
(\mathbf{m g} / \mathbf{k g})\end{array}$ & $\begin{array}{c}\mathbf{K} \\
(\mathbf{m g} / \mathbf{k g})\end{array}$ & $\begin{array}{c}\mathrm{Ca} \\
(\mathbf{m g} / \mathbf{k g})\end{array}$ & $\begin{array}{c}\mathbf{M g} \\
(\mathbf{m g} / \mathbf{k g})\end{array}$ & Total C (\%) \\
\hline \multirow{2}{*}{ Guam } & $0-10$ & 4.9 & 0.25 & 1.20 & 590 & 3232 & 2122 & 3.97 \\
& $10-30$ & 5.2 & 0.09 & 0.21 & 167 & 2006 & 2114 & 1.15 \\
\hline \multirow{2}{*}{ Rota } & $0-10$ & 5.0 & 0.18 & 0.77 & 363 & 2373 & 1449 & 3.12 \\
& $10-30$ & 5.1 & 0.10 & 1.04 & 298 & 9922 & 1130 & 2.02 \\
\hline \multirow{2}{*}{ Yap } & $0-10$ & 5.5 & 0.09 & 0.92 & 69 & 562 & 273 & 1.92 \\
& $10-30$ & 5.4 & 0.05 & 0.36 & 43 & 292 & 205 & 1.10 \\
\hline
\end{tabular}

\subsection{Seeding Growth on Guam}

The Acacia auriculiformis seedlings grew well in the Guam trial with a mean height increase of $141 \mathrm{~cm}(+/-43 \mathrm{~cm}$ std dev) over 11 months. The fastest growing tree increased in height by $246 \mathrm{~cm}$. Fertilization rate had no significant effect on absolute or relative height growth. Lime application had a significant positive effect on relative height growth $(p=0.046)$. The effect was small, however, with treated trees growing about 2.6 times their initial height compared with untreated trees growing about 2.4 times their initial height.

\subsection{Seedling Growth on Rota}

Typhoon Yutu struck the island of Rota two months after planting. As the planting site was in an exposed area, many of the Acacia confusa seedlings were damaged and all were stressed. Mortality was $6 \%$ in the first year while only one seedling died the second year. Overall, average height growth in all treatments was $16 \mathrm{~cm}(+/-8.7 \mathrm{~cm}$ std dev) after 7 months and $86 \mathrm{~cm} \mathrm{(+/}-43 \mathrm{~cm}$ std dev) after 24 months. The fastest growing seedlings grew $89 \mathrm{~cm}$ in the first period and $183 \mathrm{~cm}$ by the end of the second year. Trees in the lowest block on the slope grew more than twice as much as trees in the uppermost block $(p=0.034)$. There were no significant interactions between fertilizer and lime treatments. Applying 
double the number of fertilizer tabs significantly increased the relative height growth in the first 7 months $(p=0.054)$ and after 2 years $(p=0.088)$. Lime did not significantly affect absolute or relative height growth.

\subsection{Seedling Growth on Yap}

The Swietenia macrophylla seedlings grew well over the 11-month trial period. In the lime trial, height growth averaged $108 \mathrm{~cm}(+/-48 \mathrm{~cm}$ std dev), with the fastest growing tree increasing $246 \mathrm{~cm}$ in height. Lime treatment had no significant effect on absolute growth or relative growth rates. In the mulch trial, seedlings grew an average of $110 \mathrm{~cm}$ $(+/-48 \mathrm{~cm}$ std dev), with the fastest growing tree increasing $300 \mathrm{~cm}$ in height. Mulch application significantly increased absolute height increment $(p=0.006)$ and relative height growth $(p=0.046)$. Relative height growth was $60 \%+/-14 \%$ SE in un-mulched plots compared with $100 \%+/-14 \%$ SE in mulched plots.

\section{Discussion}

\subsection{Soils}

The soils data largely conformed to expected soil properties from the islands, although the data from Guam indicated that the plantings were located mainly on the associated Akina series rather than the Agfayan series that was mapped for the site. Whereas soil maps accurately plot soil series at a landscape scale, results on a plot scale can vary. The higher cation levels on Guam and Rota could be explained by the geology of those islands. Although the experimental site on Guam was on the volcanic uplands, it was directly downslope from a road that had been constructed over a crushed limestone bed. The Talakhaya area on Rota where the study was performed is the only area on the island where soils are derived from volcanic rocks and is directly downslope from limestone cliffs. On Yap, the soil was less strongly acid ( $\mathrm{pH}$ 5.5), and aluminum toxicity is not expected at that $\mathrm{pH}$. Although the Gagil series is usually strongly acid, the planting site showed signs of serious erosion and some of the trees may have been put into weathered saprolite, where there would be less soluble aluminum.

\subsection{Seedling Growth}

Liming soils can improve tree growth by increasing supplies of $\mathrm{Ca}$ and $\mathrm{Mg}$ and by raising soil $\mathrm{pH}$ to ameliorate aluminum toxicity [35]. The relatively high levels of $\mathrm{Ca}$ and $\mathrm{Mg}$ in the unamended soils on Rota and Guam indicate that trees on those sites would likely not be limited by those nutrients. On the Guam site, the soil was mapped as the Agfayan series, which is usually only slightly acid, but our samples from the site were very strongly acid at $\mathrm{pH}$ 4.9. It is likely that the planting site included both Akina and Agfayan series soils. A response to liming would not be expected in the slightly acid Agfayan series. Even if some seedlings had been planting on inclusions of the Akina series, the application of lime into planting holes surrounding the seedlings would have increased availability of $\mathrm{Ca}$ and $\mathrm{Mg}$ but not ameliorated soil acidity, as it was not thoroughly mixed into the soil. On the Rota site, the Akina series soils are part of the Akina-badland complex. Many of the trees in the trial were planted directly into the weathered saprolite on a degraded ridge, which would not have been as acidic as the surrounding soil. Improved growth because of the added fertilizer was expected at this site. Foresters on Guam are currently experimenting with mixing biochar into planting holes to improve tree growth [36,37].

Soil acidity problems can be managed by either ameliorating soils or by choosing crops tolerant of soil acidity. Acacia auriculiformis and A. confusa are both known to be tolerant of acid soils $[35,38]$ and were selected after trials of over two dozen other species on acid soils on Guam [29]. It is possible that the lack of lime response in our study, even in strongly acid soils, is due to selection of tree species that can tolerate these conditions. On an extremely acid soil ( $\mathrm{pH}$ 4.4) in Hawai' $\mathrm{i}$, Cole et al. [39] found that Acacia auriculiformis diameter growth responded to lime application, but the Guam and Rota soils are not as acidic as the Hawai' $i$ soil. 
The Swietenia macrophylla seedlings on Yap had already reached an average height of $160 \mathrm{~cm}$ at the beginning of the experiment. Soil in the planting holes had been ameliorated and mulched previously, which may explain the initial good growth, but the trees seemed to be at risk of a "flower pot" effect where root growth was confined to the planting hole. Roots were observed spreading out as far as the trees were mulched (to about $20 \mathrm{~cm}$ from the stems), but no further. Although lime was tilled into the soil to encourage root expansion, there was no effect in the first year after application. Similarly, Cannon et al. [40] did not find any lime effect on height growth of Acacia auriculifomis seedlings on the same soil series on Yap, although $A$. auriculiformis is more acid tolerant than S. macrophylla. The Yap soil was strongly acid ( $\mathrm{pH}$ 5.5) but may not have been acid enough to cause aluminum toxicity. $\mathrm{Al}^{3+}$ is the most toxic form of aluminum in soils and predominates at $\mathrm{pH}$ values below 5.0, whereas the less toxic forms, $\mathrm{AlOH}^{2+}$ and $\mathrm{Al}(\mathrm{OH})_{2}{ }^{+}$, predominate at $\mathrm{pH}$ values of 5.0 to 6.0 [41].

Swietenia macrophylla seedlings did respond to mulching on Yap. On the neighboring island of Palau, with similar, but more weathered, soils, mulching of Acacia auriculiformis plantings along with applications of fertilizer and lime reversed a marked stress condition of the trees and restored healthy crowns [42]. When also working on Palau, Dendy et al. [24] did not find that mulching improved growth of either naturally occurring saplings or planted seedlings of various native species, perhaps because they applied a much thinner layer of mulch than was applied in the current study $(2 \mathrm{~cm}$ vs. $10 \mathrm{~cm})$. Mulching can have many effects on plant growth, including nutrient supply from decomposing organic matter, soil moisture retention, weed suppression, and reduction of soil solar heating. Much of the planting site on Yap was bare soil without any vegetation, so these mechanisms, with the exception of weed suppression, may explain the significant response to mulch. Organic matter from mulch can help complex soil Al and reduce toxicity [43], although if Al toxicity had been a factor, the lime treatment would likely have had an effect. Experiments with artificial mulches that help retain soil moisture, suppress weeds, and reduce soil heating but do not contribute to soil nutrients could help to further understand the mechanisms whereby mulch influences seedling growth.

\subsection{Management Challenges and Implications}

The success of the various trials as demonstrations to catalyze change was mixed.

For the Guam site, the standard practice of applying just $15 \mathrm{~g}$ of complete fertilizer and no lime proved just as effective as increased fertilization or application of lime and provided little reason for Guam Forestry to modify their current practices for establishing Acacia auriculiformis.

On Rota, the trial showed that doubling the amount of fertilizer significantly increased tree growth, which can decrease the time needed to reach canopy closure and shade out grasses, thus reducing risk of wildfires. In subsequent plantings, Rota Forestry has increased the fertilizer amount per tree.

The most encouraging result was the increased growth with mulching in the Swietenia macrophylla seedlings on Yap. The experimental results validated the traditional technique of ameliorating soil acidity through mulch application, which was more effective than the modern technique of applying lime. Local community members on Yap were involved with the installation of the mulch and lime trial, and the results were shared with other community members at a meeting. The community was interested not only because the trees could provide a firebreak for the village, but also because they were beginning to bring other areas with similar soils under cultivation and were looking for information on how to improve these soils.

While mulching is traditionally used as an agricultural technique on Yap, mulch is only applied to relatively small plots in forest gardens [44]. It will be challenging to scale up the technique to meet the demands of landscape-scale reforestation. Mulching was feasible on the current project because the site was flat, adjacent to a road, and had an 
abundance of local vegetation that could be chipped for mulch. The Rota site, in contrast, was on a steep slope almost one kilometer from the road.

All three sites used non-native tree species. On Guam and Rota, the non-native Acacia spp. were planted for the ecosystem service of shading out grasses rather than wood production. Acacia spp. were introduced to those islands decades ago, before widespread concern about invasive species $[25,45]$. Acacia trees have become invasive in many ecosystems where they have been introduced [46], including the Pacific Islands, and would not be recommended for introduction to new areas today. The situation of Guam is unusual because the absence of native forest birds extirpated by the invasive brown tree snake (Boiga irregularis) has eliminated the seed dispersers on the island and thus limited the spread of Acacia spp. [47]. While the long-term vision is to transition to native tree species such as Cerbera dilatata Markgr., Intsia bijuga (Colebr.) Kuntze, Morinda citrifolia L., and Premna serratifolia L. planted in gaps or the understory of the plantations, native trees planted alone in adjacent grasslands have not grown well. Foresters are also experimenting with plantings of the native fast-growing, nitrogen-fixing tree Pterocarpus indicus Willd. for grassland reforestation.

On Rota, local foresters have observed behavior of Acacia confusa in plantations since the 1930s and concluded that the tree poses a low risk of invasiveness. Unprotected seedlings of native trees such as Elaeocarpus joga Merr., Hernandia labyrinthica Tuyama, Intsia bijuga, and Serianthes nelsonii Merr. have been almost completely destroyed by deer. Rota Forestry is currently experimenting with fences and other exclosures to enable an increase in the use of native trees in reforestation projects.

On Yap, foresters are planting mixed-species greenbelts including the non-native but non-invasive and economically valuable Swietenia macrophylla, the non-native fruit-bearing trees Inocarpus fagifer (Parkinson) F.R. Fosberg and Cocos nucifera L., the native timber trees Pterocarpus indicus and Calophyllum inophyllum, and a number of native trees and shrubs including Premna serratifolia, Barringtonia racemosa Roxb., and Scaevola taccada (Gaertn.) Roxb. The emphasis is on trees that will not only shade out flammable grasses and ferns but also provide products for the adjacent community when managed similarly to the traditional agroforestry system $[44,48]$.

Small, locally managed afforestation projects, including projects on small islands, face a number of difficulties in improving their site assessment, installing and evaluating trials, and using the information to improve the following year's plantings [31]. Even on Guam, which has a four-year university, the soil laboratory capabilities are limited. Samples had to be shipped to Florida for analysis of P, an extra step that the local forestry agency on Guam would be unlikely to do. Rota and Yap samples had to be shipped to Guam for analysis, and Yap Forestry had difficulty paying for the shipping, even though the analysis was performed for free. Furthermore, shipping samples from Rota to Guam required permits, and shipping samples from Yap to Guam required international permits.

Although $\mathrm{pH}$ meters can be used in the field and give immediate results that are useful for diagnosing soil conditions, particularly acidity, they require training on how to use and calibrate. Additionally, buffer solutions for calibration are not available locally. $\mathrm{pH}$ meters that were left with forestry agencies were not subsequently used by the agencies. Furthermore, supplies of agricultural materials are limited on all three islands. Even on Guam, the local agriculture supply store did not stock agricultural lime, and the only lime available on island was in small bags sold for home gardeners at a hardware store. Island forestry agencies can order supplies if budgets allow, but because of limited transportation to smaller islands, orders often do not arrive in time for planting.

None of the agencies had staff with the ability to analyze data and discern differences that were not immediately obvious in the field. Even small forestry operations could improve their success, however, if staff were trained to observe field differences in soils and adjust planting recommendations based on observed soil characteristics. On Guam, for instance, the acidic Akina series is reddish in color whereas the more neutral Agfayan series is brown or tan (Figure 7a,b). 


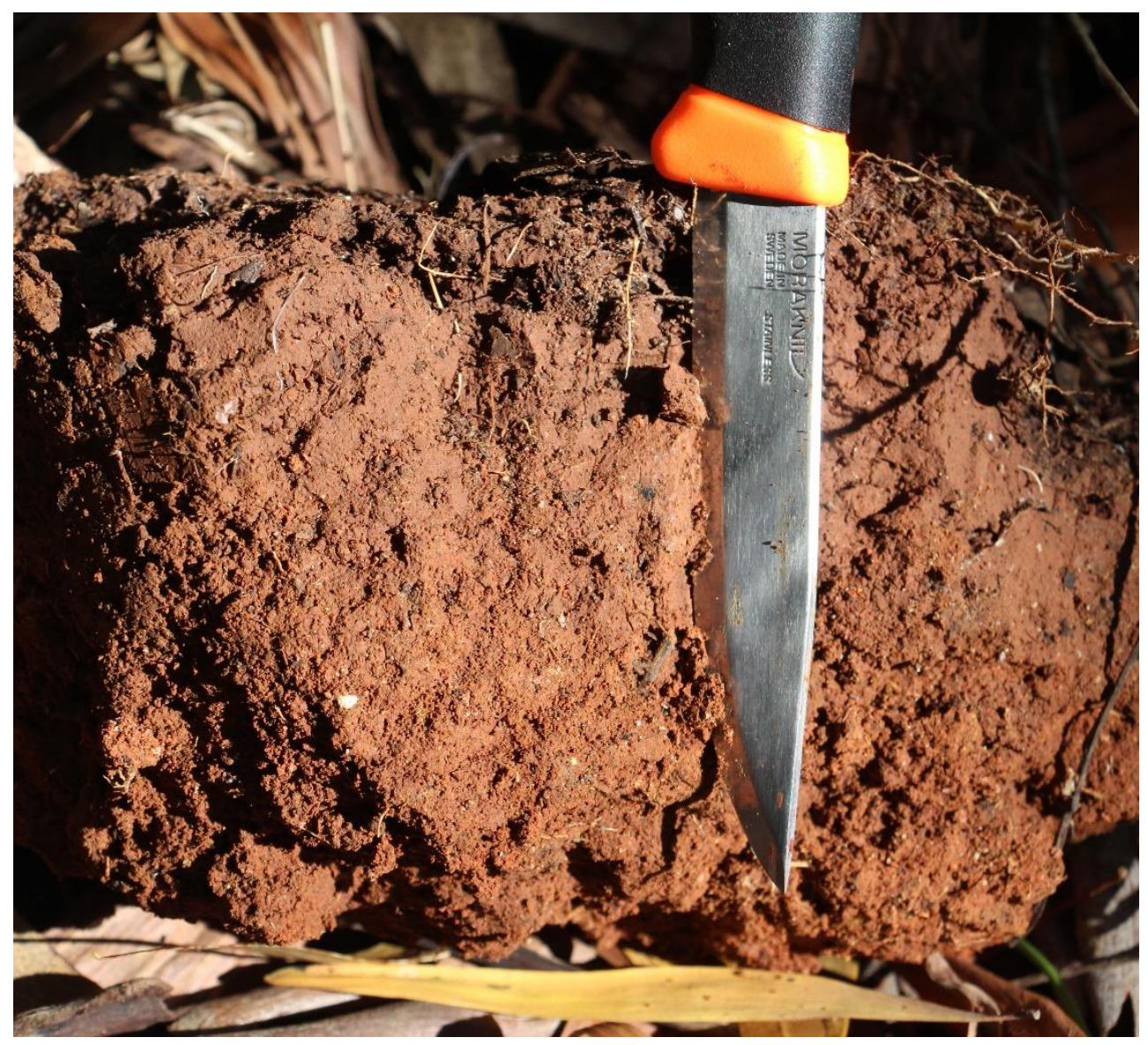

(a)

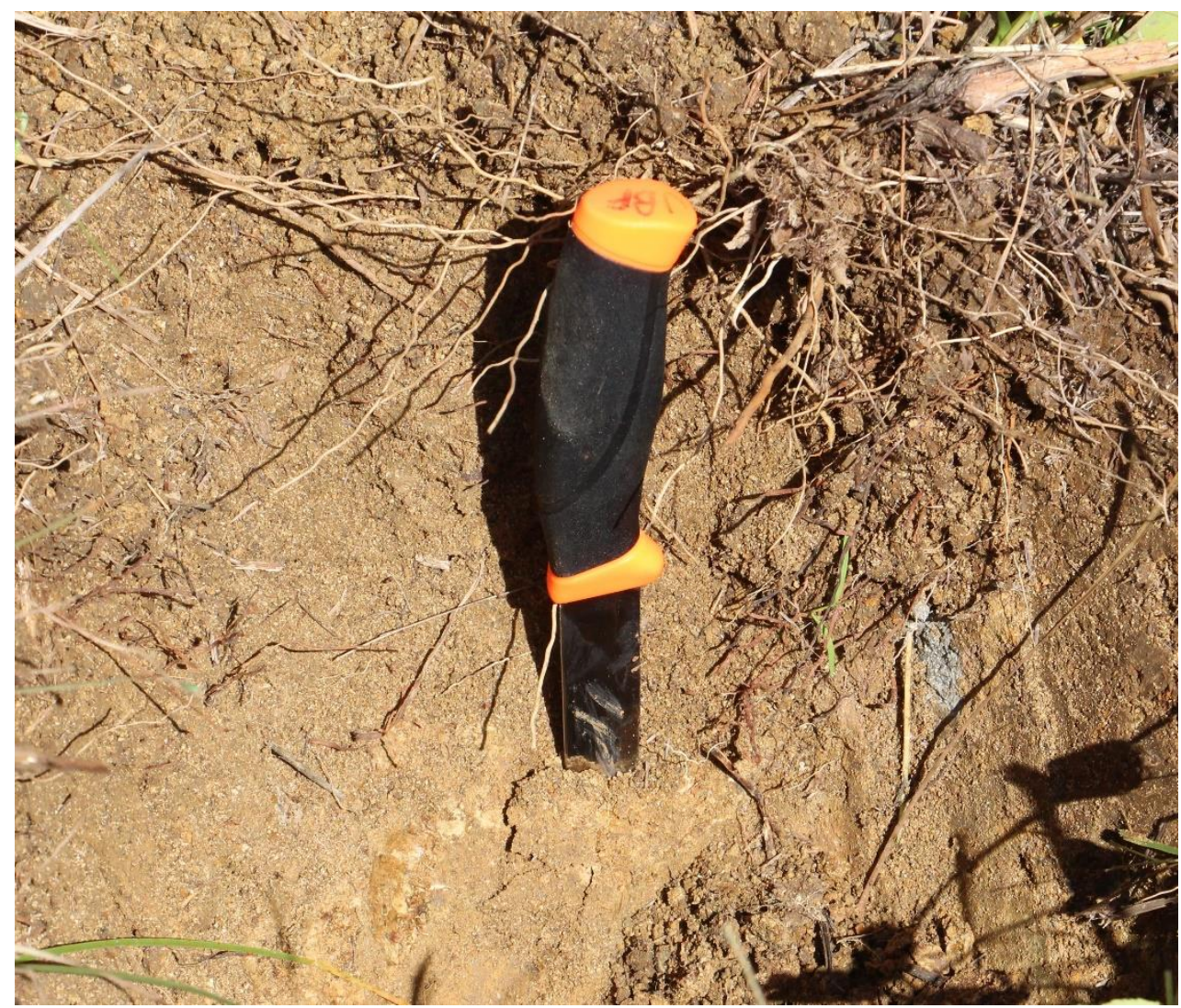

(b)

Figure 7. (a) Akina series soil and (b) Agfayan series soil, Guam. 
Planting crews could be instructed to add additional amendments in sites with red soils. Both forestry staff and the local community on Yap have a basic understanding of the main soil types on the island and their properties, and a soils map was hanging in the community center at the time of our presentation.

For the American-affiliated Pacific Islands, the U.S. Department of Agriculture Natural Resource Conservation Service has mapped soils and publishes online maps of soils and their properties as part of the Web Soil Survey [23]. Training local agencies in the use of online resources such as this could also help improve reforestation success.

Improved collaboration between universities and forestry agencies could help agencies with trial implementation, data analysis, and interpretation of results. The two-year college on Yap has a small agriculture program, and faculty and students there could work with Yap Forestry in designing future trials and evaluating other techniques for improving tree growth. On Rota, there is an extension station, which is a branch of the College of the Northern Mariana Islands. Off-island assistance could also be a valuable resource. The University of Idaho helped the Government of Lebanon improve reforestation success, with seedling survival increasing from $10-40 \%$ to $70-90 \%$ percent through a close and sustained collaboration with frequent communication [49].

\section{Conclusions}

Scientists working out of well-funded universities can install experiments that diagnose problems in reforestation, but unless proposed solutions are locally adopted, the knowledge gained from experiments will not help improve reforestation success [50]. Results that are put into practice require techniques that can be locally applied using materials that are locally available. Decision support tools using information that is readily available to local agencies could help improve reforestation success. University-based researchers can assist with experimental design and analysis [51] in collaboration with agency staff and can guide local forestry agencies in developing adaptive management methods to address local problems. Foresters should also make use of local knowledge of environmental conditions and traditional methods to compensate for limiting factors such as soil acidity.

Author Contributions: Conceptualization, J.B.F., D.L.H., R.E., J.M., and R.T.; methodology, J.B.F.; data analysis, J.B.F.; investigation, J.B.F., D.L.H., R.E., J.M., and R.T.; resources, R.E., J.M., and R.T.; writingoriginal draft preparation, J.B.F.; writing-review and editing, D.L.H., R.E., J.M., and R.T.; funding acquisition, J.B.F. All authors have read and agreed to the published version of the manuscript.

Funding: This research was funded by the USDA Forest Service, grant number 17-CA-11062765-702.

Data Availability Statement: The data from this study are available upon request from the corresponding author.

Acknowledgments: We thank the forestry staff on Guam, Rota, and Yap for their assistance in planting and fertilizing seedlings and taking measurements. We thank the community of Tomil on Yap for both field assistance and constructive dialog on soil fertility. Jonathan Deenik and Robert Gavenda provided helpful comments on the manuscript.

Conflicts of Interest: DH is an employee of the USDA Forest Service and is the manager of the program that funded this research.

\section{References}

1. Ancog, R.C.; Florece, L.M.; Nicopior, O.B. Fire occurrence and fire mitigation strategies in a grassland reforestation area in the Philippines. For. Policy Econ. 2016, 64, 35-45. [CrossRef]

2. Turvey, N.G. Afforestation and Rehabilitation of Lmperata Grasslands in Southeast Asia: Identification of Priorities for Research, Education, Training and Extension; ACIAR Technical Reports No. 28; ACIAR: Canberra, Australia, 1994; 52p.

3. Kepler, C.B.; Irvine, G.W.; DeCapita, M.E.; Weinrich, J. The conservation management of Kirtland's Warbler Dendroica kirtlandii. Bird Conserv. Int. 1996, 6, 11-22. [CrossRef]

4. Nepstad, D.; Carvalho, G.; Barros, A.C.; Alencar, A.; Capobianco, J.P.; Bishop, J.; Moutinho, P.; Lefebvre, P.; Silva, U.L.; Prins, E. Road paving, fire regime feedbacks, and the future of Amazon forests. For. Ecol. Manag. 2001, 154, 395-407. [CrossRef] 
5. D'Antonio, C.M.; Vitousek, P.M. Biological Invasions by Exotic Grasses, the Grass/Fire Cycle, and Global Change. Annu. Rev. Ecol. Syst. 1992, 23, 63-87. [CrossRef]

6. Athens, S.J.; Ward, J.V. Holocene vegetation, savanna origins and human settlement of Guam. In A Pacific Odyssey: Archaeology and Anthropology in the Western Pacific; Suppl. 29; Attenbrow, V., Fullagar, R., Eds.; Papers in Honour of Jim Specht. Records of the Australian Museum; Australian Museum: Sydney, Australian, 2004; pp. 15-30.

7. Costion, C.M.; Liston, J.; Kitalong, A.H.; Iida, A.; Lowe, A.J. Using the ancient past for establishing current threat in poorly inventoried regions. Biol. Conserv. 2012, 147, 153-162. [CrossRef]

8. Dodson, J.R.; Intoh, M. Prehistory and paleoecology of Yap, Federated States of Micronesia. Quatern. Int. 1999, 59, 17-26. [CrossRef]

9. Pacific Fire Exchange. Wildfire in the Western Pacific. University of Hawai'i, Honolulu. 2017. Available online: https: //www.pacificfireexchange.org/research-publications/category/wildfire-in-the-western-pacific (accessed on 21 August 2021).

10. Donnegan, J.A.; Butler, S.L.; Grabowiecki, W.; Hiserote, B.; Limtiaco, D. Guam's Forest Resources, 2002; US Department of Agriculture, Forest Service, Pacific Northwest Research Station: Portland, OR, USA, 2004; p. 32. Available online: https: / / www.fs.usda.gov/treesearch/pubs/7542 (accessed on 24 July 2021).

11. Donnegan, J.A.; Butler, S.L.; Kuegler, O.; Hiserote, B.A. Commonwealth of the Northern Mariana Islands' Forest Resources, 2004; Resource Bulletin PNW-RB-261; US Department of Agriculture, Forest Service, Pacific Northwest Research Station: Portland, OR, USA, 2011; p. 46. Available online: https:/ / www.fs.usda.gov/treesearch/pubs/39461 (accessed on 24 July 2021).

12. Donnegan, J.A.; Butler, S.L.; Kuegler, O.; Hiserote, B.A. Federated States of Micronesia's Forest Resources, 2006; Resource Bulletin PNW-RB-262; US Department of Agriculture, Forest Service, Pacific Northwest Research Station: Portland, OR, USA, $2011 ;$ p. 56. Available online: https:/ / www.fs.usda.gov/treesearch/pubs/39459 (accessed on 24 July 2021).

13. Pacific Fire Exchange. 2019 Wildfire summary in the Western Pacific. University of Hawai'i, Honolulu. 2020. Available online: https:/ / www.pacificfireexchange.org/research-publications/category/2019-wildfire-summary-in-the-western-pacific (accessed on 22 July 2021).

14. Endress, B.A.; Chinea, J.D. Landscape patterns of tropical forest recovery in the Republic of Palau. Biotropica $2001,33,555-565$. [CrossRef]

15. Trauernicht, C.; Pickett, E.; Giardina, C.P.; Litton, C.M.; Cordell, S.; Beavers, A. The Contemporary Scale and Context of Wildfire in Hawai'i. Pac. Sci. 2015, 69, 427-444. [CrossRef]

16. Pacific Fire Exchange. 2018 Western Pacific Wildfires: PFX Annual Summary. University of Hawai'i, Honolulu. 2019. Available online: https:/ / www.pacificfireexchange.org/research-publications/category/2018wpacificsummary (accessed on 21 August 2021).

17. Western Regional Climate Center. 2021. Available online: https:/ / wrcc.dri.edu/ (accessed on 28 July 2021).

18. Mafnas, J.S. Guam Statewide Forest Resource Assessment and Resource Strategy. 2010. Available online: https://www. stateforesters.org/wp-content/uploads/2018/08/Guam-FAP.pdf (accessed on 24 July 2021).

19. Commonwealth of the Northern Mariana Islands Statewide Assessment and Resource Strategy Council. Commonwealth of the Northern Mariana Islands (CNMI) Statewide Assessment and Resources Strategy 2010-2015+. 2010. Available online: https://www.stateforesters.org/wp-content/uploads/2018/08/CNMI_FAP.pdf (accessed on 24 July 2021).

20. Minton, D. Fire, Erosion, and Sedimentation in the Asan-Piti Watershed and War in the Pacific NHP, Guam. Pacific Cooperative Studies Unit, University of Hawai'i. 2006. Available online: https://scholarspace.manoa.hawaii.edu/bitstream/10125/836/v150 .pdf (accessed on 21 August 2021).

21. Shelton, A.J.; Richmond, R.H. Watershed restoration as a tool for improving coral reef resilience against climate change and other human impacts. Estuar. Coast. Shelf Sci. 2016, 183, 430-437. [CrossRef]

22. Fabricius, K.E. Effects of terrestrial runoff on the ecology of corals and coral reefs: Review and synthesis. Mar. Pollut. Bull. 2005, 50, 125-146. [CrossRef]

23. US Department of Agriculture Natural Resource Conservation Service Web Soil Survey. Available online: https: / websoilsurvey. sc.egov.usda.gov / App/WebSoilSurvey.aspx (accessed on 20 May 2021).

24. Dendy, J.; Cordell, S.; Giardina, C.P.; Hwang, B.; Polloi, E.; Rengulbai, K. The role of remnant forest patches for habitat restoration in degraded areas of Palau. Restor. Ecol. 2015, 23, 872-881. [CrossRef]

25. DeBell, D.S.; Whitesell, C.D. Upland Forests of the American/Pacific Islands: Research Opportunities in Micronesia and American Samoa; General Technical Report PSW-GTR-145; Department of Agriculture, Forest Service, Pacific Southwest Research Station: Albany, CA, USA, 1993; p. 14. Available online: https://www.fs.usda.gov/treesearch/pubs/27280 (accessed on 17 July 2021).

26. Young, F.J. Acid soils of Guam. In Proceedings of the Third International Soil Management Workshop on the Management and Utilization of Acid Soils of Oceania, Palau, 2-6 February 1987; Demeterio, J.L., DeGuzman, B., Eds.; University of Guam: Mangilao, Guam, 1987; pp. 114-127.

27. Federated States of Micronesia Department of Resources and Development. Federated States of Micronesia Forest Action Plan 2020-2030. 2020. Available online: https:/ / www.stateforesters.org/wp-content/uploads/2021/02/FSM-Forest-Action-Plan2020-2030-Jan24-FINAL.pdf (accessed on 24 July 2021).

28. Mueller-Dombois, D.; Fosberg, F.R. Vegetation of the Tropical Pacific Islands; Springer: New York, NY, USA, $1998 ;$ p. 733.

29. Newell, L. Afforestation of eroded acidic soils in southern Guam. In Proceedings of the Third International Soil Management Workshop on the Management and Utilization of Acid Soils of Oceania, Palau, 2-6 February 1987; Demeterio, J.L., DeGuzman, B., Eds.; University of Guam: Mangilao, Guam, 1987; pp. 196-203. 
30. National Oceanic and Atmospheric Administration Coral Reef Conservation Program. Restoring Talakhaya Watershed in the Commonwealth of the Northern Mariana Islands. 2016. Available online: https://coralreef.noaa.gov/aboutcrcp/news/ featuredstories/sep16/talakhaya.html (accessed on 24 July 2021).

31. Dumroese, K.R.; Landis, T.D.; Pinto, J.R.; Haase, D.L.; Wilkinson, K.W.; Davis, A.S. Meeting Forest Restoration Challenges: Using the Target Plant Concept. Reforesta 2016, 1, 37-52. [CrossRef]

32. Hue, N.V.; Uchida, R.; Ho, M.C. Sampling and analysis of soils and plant tissues. In Plant Nutrient Management in Hawaii's Soils: Approaches for Tropical and Subtropical Agriculture; Silva, J.A., Uchida, R., Eds.; University of Hawai'i: Honolulu, HI, USA, 2000; pp. 23-30.

33. Olsen, S.R.; Sommers, L.E. Phosphorus. In Methods of soil analysis: Part 2. Chemical and Microbiological Properties; Page, A.L., Ed.; American Society of Agronomy and Soil Science Society of America: Madison, WI, USA, 1982; pp. 403-430.

34. Burt, R. (Ed.) Soil Survey Laboratory Information Manual; USDA Natural Resource Conservation Service: Lincoln, NE, USA, 2011.

35. Marcar, N.E.; Khanna, P.K. Reforestation of salt-affected and acid soils. In Management of Soil, Nutrients, and Water in Tropical Plantation Forests; Nambiar, E.K.S., Brown, A.G., Eds.; ACIAR: Canberra, Australia, 1997; pp. 481-518.

36. Dumroese, R.K.; Page-Dumroese, D.S.; Pinto, J.R. Biochar potential to enhance forest resilience, seedling quality, and nursery efficiency. Tree Plant. Notes 2020, 63, 61068.

37. Rockwood, D.L.; Ellis, M.F.; Liu, R.; Zhao, F.; Ji, P.; Zhu, Z.; Fabbro, K.W.; He, Z.; Cave, R.D. Short Rotation Eucalypts: Opportunities for Biochar. Forests 2019, 10, 314. [CrossRef]

38. Powell, M. Nitrogen fixing trees and shrubs for acid soils: An overview. In Nitrogen Fixing Trees for Acid Soils; Evans, D.O., Szott, L.T., Eds.; Winrock International/Nitrogen Fixing Tree Association: Morrilton, AR, USA, 1995; pp. $185-194$.

39. Cole, T.G.; Yost, R.S.; Kablan, R.; Olsen, T. Growth potential of twelve Acacia species on acid soils in Hawaii. For. Ecol. Manag. 1996, 80, 175-186. [CrossRef]

40. Cannon, P.; Friday, J.B.; Liyag, F.; Greenberg, D. Forest restoration on degraded soils in Yap, Federated States of Micronesia. Tree Plant. Notes 2021, 64, 39-46.

41. Bojórquez-Quintal, E.; Escalante-Magaña, C.; Echevarría-Machado, I.; Martínez-Estévez, M. Aluminum, a Friend or Foe of Higher Plants in Acid Soils. Front. Plant Sci. 2017, 8, 1767. [CrossRef] [PubMed]

42. US Department of Agriculture Natural Resource Conservation Service No Date; US Forest Service and Palau Forestry Reclaim Degraded Lands in Babeldaob; NRCS Field Office: Palau.

43. Hue, N.V.; Amien, I. Aluminum detoxification with green manures. Commun. Soil Sci. Plant Anal. 1989, 20, 1499-1511. [CrossRef]

44. Falanruw, M.V.C. Micronesian agroforestry: Evidence from the past, implications for the future. In Proceedings of the Workshop on Research Methodologies and Applications for Pacific Island Agroforestry, Kolonia, Pohnpei, 16-20 July 1990; Raynor, B., Bay, R.R., Eds.; Technical Coordinators; Federated States of Micronesia. Gen. Tech. Rep. PSW-GTR-140. Pacific Southwest Research Station, USDA Forest Service: Albany, CA, USA, 1993; pp. 37-41.

45. Hughes, C.E. Risks of species introductions in tropical forestry. Commonw. Forest. Rev. 1994, 73, $243-252$.

46. Kull, C.A.; Shackleton, C.M.; Cunningham, P.J.; Ducatillon, C.; Dufour-Dror, J.; Esler, K.J.; Friday, J.B.; Gouvia, A.C.; Griffin, A.R.; Marchante, E.; et al. Adoption, use and perception of Australian acacias around the world. Divers. Distrib. 2011, 17, 822-836. [CrossRef]

47. Wiles, G.J.; Bart, J.; Beck, R.E.; Aguon, C.F. Impacts of the Brown Tree Snake: Patterns of Decline and Species Persistence in Guam's Avifauna. Conserv. Biol. 2003, 17, 1350-1360. [CrossRef]

48. Falanruw, M.C.; Whitesell, C.D.; Cole, T.G.; MacLean, C.D.; Ambacher, A.H. Vegetation survey of Yap, Federated States of Micronesia; Res. Bull PSW-RB-21; U.S. Department of Agriculture, Forest Service, Pacific Southwest Forest and Range Experiment Station: Berkeley, CA, USA, 1987.

49. Kildisheva, O.A.; Aghai, M.M.; Bouazza, K.; Davis, A.S. Improving restoration success through research-driven initiatives: Case studies targeting Pinus pinea reforestation stock development in Lebanon. Plant Ecol. 2017, 218, 39-53. [CrossRef]

50. Ewel, K.C. Natural Resource Management: The Need for Interdisciplinary Collaboration. Ecosystems 2001, 4, 716-722. [CrossRef]

51. Haase, D.L. Beyond cowboy science: Simple methods for conducting credible and valid research. Tree Plant. Notes 2014, 57, 32-43. 